\title{
Nutrient extraction by mombaça grass submitted to sources and doses of nitrogen
}

\author{
Extracción de nutrientes por el capín mombaça sometido \\ a fuentes y dosis de nitrógeno
}

\author{
Thiago Lopes Rosado ${ }^{*}$, Ivoney Gontijo², Renato Ribeiro Passos ${ }^{3}$, Marcelo Suzart de Almeida ${ }^{2}$
}

\begin{abstract}
The extraction of nutrients from the soil by plants depends on soil fertility, plant management and plant production. The objective of this study was to evaluate the effect of the application of sources and doses of nitrogen on macronutrient extraction by Panicum maximum cv. Mombaça. The experiment was conducted from 1 October 2011 to 14 April 2012 in the Federal Institute of Espírito Santo, Santa Teresa Campus. The experimental design was a randomised block design with three repetitions in a $3 \times$ 6 factorial scheme, with three nitrogen fertilisers (urea, ammonium sulphate and calcium nitrate) and six nitrogen doses $(0,120$, $240,360,480$ and $600 \mathrm{~kg} \mathrm{ha}^{-1}$ ). The established nitrogen doses were divided equally and applied every 28 days after the mombaça grass was cut, resulting in a total of seven applications during the 196-day experimental period. It was observed than nutrient extraction depends on forage plant production and was highest with the higher doses of nitrogen because of the greater dry matter production. The application of high doses of nitrogen in the form of calcium nitrate caused a reduced absorption of magnesium. Nitrogen fertilisation in pastures should be accompanied by the management of other nutrients to avoid nutritional imbalances or the depletion of soil fertility.
\end{abstract}

Key words: Panicum maximum, nitrogen fertilisers, macronutrient absorption, interaction between ions.

\section{RESUMEN}

La extracción de nutrientes depende de la fertilidad del suelo, de cómo las plantas son tratadas y de su producción. El objetivo del presente trabajo es evaluar el efecto de la aplicación de fuentes y dosis de nitrógeno sobre la extracción de macronutrientes por el Panicum maximum cv. Mombaça. El experimento se llevó a cabo entre el 1 de octubre de 2011 y el 14 de abril de 2012, en el Instituto Federal do Espíritu Santo, Campus Santa Teresa. En la delineación experimental se utilizaron bloques aleatorios, con tres repeticiones, en un esquema factorial $3 x$ 6: tres fertilizantes nitrogenados (urea, sulfato de amonio y nitrato de calcio) y seis dosis de nitrógeno $\left(0,120,240,360,480\right.$ y $\left.600 \mathrm{~kg} \mathrm{ha}^{-1}\right)$. Las dosis de nitrógeno establecidas se dividieron y se aplicaron de igual forma cada 28 días, siempre después del corte del capín mombaca, con un total de siete aplicaciones durante el período experimental de 196 días. Se observó que la extracción de nutrientes depende de la producción del forraje, y es mayor para las dosis más elevadas de nitrógeno, debido a la mayor producción de materia seca. La aplicación de elevadas dosis de nitrógeno, en la forma de nitrato de calcio, promovió la reducción de la absorción de magnesio. La fertilización nitrogenada en pastos debe estar acompañada por el manejo de los demás nutrientes, tratando de evitar el desequilibrio nutricional o el agotamiento de la fertilidad del suelo.

Palabras clave: Panicum máximum, fertilizantes nitrogenados, absorción de macronutrientes, interacción entre iones.

\section{Introduction}

The ability to graze livestock is, without a doubt, one of the greatest reasons for the success of the Brazilian cattle industry, as it allows for lower production costs and increases the competitiveness of national livestock production while helping producers overcome health problems that could

1 Federal Institute of Espirito Santo. Santa Teresa, ES, Brazil.

2 Biological and Agricultural Sciences Department, Federal University of Espirito Santo. São Mateus, ES, Brazil.

3 Plant Production Department, Federal University of Espirito Santo. Alegre, ES, Brazil.

* Corresponding author: thiagolr@ifes.edu.br

Fecha de Recepción: 9 Marzo, 2016.

Fecha de Aceptación: 25 Febrero, 2017.

DOI: $10.4067 / \mathrm{S} 0718-34292017005000009$ 
constitute barriers to entry into the international market (Almeida et al., 2011). However, meat and milk production could reach higher levels than the currently observed levels. This has not occurred because, among other reasons, the low production and quality of the forage given to the animals limits their performance (Santos et al., 2016).

Numerous factors contribute to the low productivity of Brazilian pastures. However, the factors related to the management of soil fertility are worth mentioning. Forage production is not only impaired by the absence of nutrients; multiple management-related deficiencies, including the absence of soil acidity correction and fertiliser use, also limit the productivity of pastures (Barcellos et al., 2008).

Nitrogen $(\mathrm{N})$ is one of the most important nutrients that limits production in tropical forage grasses, as it is quantitatively the most important nutrient for plant growth (Primavesi et al., 2005). It is essential to plants because it is found in some of the most important plant biomolecules, including amino acids, proteins, nucleic acids, hormones, enzymes, coenzymes, phytochromes, chlorophyll, ATP, NADH and NADPH (Taiz \& Zeiger, 2009). N deficiency limits the productivity of forage grasses, which results in a sharp decline in the stocking rate of pastures and consequently reduced animal weight (Alves et al., 2015).

In an attempt to increase pasture productivity, nitrogen fertilisers have been used to increase forage production. However, according to Primavesi et al. (2004), inadequate $\mathrm{N}$ management in pastures could produce negative effects on soil fertility, as an increase in forage production due to nitrogen fertilisers results in greater extraction of other nutrients from the soil, which if not replaced could limit the future efficiency of the nitrogen fertiliser and promote soil depletion and degradation.

Thus, knowledge of the absorption and extraction of nutrients in pastures is fundamentally important for improving the management of soil fertility in areas where nitrogen fertilisation is applied. The objective of this study was to evaluate the effect of the application of sources and doses of nitrogen on macronutrient extraction by mombaça grass (Panicum maximum Jacq.).

\section{Materials and Methods}

The experiment was conducted from 1 October 2011 to 14 April 2012, at the Federal Institute of
Espírito Santo, Santa Teresa Campus, located at coordinates $19^{\circ} 48^{\prime} 36^{\prime \prime} \mathrm{S}$ and $40^{\circ} 40^{\prime} 48^{\prime \prime} \mathrm{W}$ at an average altitude of $150 \mathrm{~m}$ in Santa Teresa, ES. The regional climate is humid temperate with a dry winter and hot summer and the region is classified as Cwa according to the Köppen classification.

The pasture was $1200 \mathrm{~m}^{2}$ with $6 \mathrm{~m}^{2}$ plots totalling $324 \mathrm{~m}^{2}$. The mombaça grass had been established for more than four years and was highly productive. Soil fertility was managed according to technical recommendations for irrigated pastures with high nutritional requirements (Prezotti et al., 2007).

The soil was a yellow Oxisol with a clay texture (Santos et al., 2013) and 343, 170 and $487 \mathrm{~g} \mathrm{~kg}^{-1}$ of sand, silt and clay, respectively. Four months before the experiment began, the soil was chemically analysed and limed 110 days before the beginning of the experiment with $1000 \mathrm{~kg} \mathrm{ha}^{-1}$ of dolomitic limestone. The fertilisation (without $\mathrm{N}$ ) occurred 90 days after the liming, according to the recommendations for mombaça grass of the Manual of Liming and Fertilisation of Espírito Santo (Prezotti et al., 2007). A total of $463 \mathrm{~kg} \mathrm{ha}^{-1}$ of triple superphosphate, $434 \mathrm{~kg} \mathrm{ha}^{-1}$ of potassium chloride and $60 \mathrm{~kg} \mathrm{ha}^{-1}$ of FTE BR-10 were applied to the experimental area. The liming and fertilization were broadcast on the surface, without incorporation. Immediately before beginning the experiment, a new soil sample was taken from the experimental area at depths of 0-0.2 and 0.2-0.4 m (Table 1).

The experimental design was a randomised block design. A 3 x 6 factorial scheme was adopted with three nitrogen fertilisers (urea, ammonium sulphate and calcium nitrate), six $\mathrm{N}$ doses $(0,120$, $240,360,480$ and $600 \mathrm{~kg} \mathrm{ha}^{-1}$ ) and three repetitions, totalling 54 experimental units.

The established $\mathrm{N}$ doses were divided equally and applied every 28 days after the mombaça grass was cut, resulting in a total of seven applications during the 196-day experimental period.

Plots of $3 \times 2 \mathrm{~m}$ were demarcated with a 1-m border. Subsequently, the entire area was uniformly cut with a brush cutter and the treatments were applied. The treatments (sources and doses of $\mathrm{N}$ ) were dissolved in $10 \mathrm{~L}$ of water and applied to the plots with a sprinkler to best distribute the nitrogen fertilisers. Immediately after applying the nitrogen fertilisers, $8 \mathrm{~mm}$ of water were applied to the entire experimental area using spray irrigation system with $74 \%$ application efficiency. 
Table 1. Chemical soil characterisation of the experimental area at depths of 0-0.2 and 0.2-0.4 m before and after liming and soil fertilisation.

\begin{tabular}{|c|c|c|c|c|c|c|c|c|c|c|c|c|}
\hline \multicolumn{13}{|c|}{ Before liming and soil fertilisation } \\
\hline Depth & $\mathrm{pH}^{1}$ & $\mathrm{Ca}$ & $\mathrm{Mg}$ & $\mathrm{Al}$ & $\mathrm{H}+\mathrm{Al}$ & CEC & SB & $\mathrm{P}$ & $\mathrm{K}$ & $\mathrm{S}-\mathrm{SO}_{4}{ }^{2-}$ & $\mathrm{OM}$ & $\mathrm{V}$ \\
\hline $\mathrm{m}$ & & \multicolumn{6}{|c|}{ 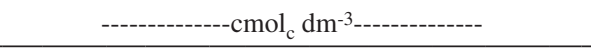 } & \multicolumn{3}{|c|}{------mg dm-3------ } & $\mathrm{g} \mathrm{kg}^{-1}$ & $\%$ \\
\hline $0-0.2$ & 5.0 & 1.7 & 0.6 & 0.3 & 3.1 & 5.5 & 2.4 & 11.0 & 30 & 6.2 & 26 & 43 \\
\hline $0.2-0.4$ & 5.4 & 1.9 & 0.6 & 0.1 & 2.8 & 5.4 & 2.6 & 3.4 & 22 & 5.5 & 22 & 48 \\
\hline \multicolumn{13}{|c|}{ After liming and soil fertilisation } \\
\hline Depth & $\mathrm{pH}^{1}$ & $\mathrm{Ca}$ & $\mathrm{Mg}$ & $\mathrm{Al}$ & $\mathrm{H}+\mathrm{Al}$ & CEC & $\mathrm{SB}$ & $\mathrm{P}$ & $\mathrm{K}$ & $\mathrm{S}-\mathrm{SO}_{4}{ }^{2-}$ & $\mathrm{OM}$ & $\mathrm{V}$ \\
\hline $\mathrm{m}$ & & \multicolumn{6}{|c|}{ - $\mathrm{cmol}_{\mathrm{c}} \mathrm{dm}^{-3}$} & \multicolumn{3}{|c|}{------mg dm-3------ } & $\mathrm{g} \mathrm{kg}^{-1}$ & $\%$ \\
\hline $0-0.2$ & 5.6 & 3.2 & 1.1 & 0.0 & 1.2 & 5.9 & 4.7 & 32.0 & 155 & 10.2 & 25 & 80 \\
\hline $0.2-0.4$ & 5.3 & 2.1 & 0.9 & 0.1 & 2.5 & 5.6 & 3.2 & 0.3 & 14 & 4.4 & 16 & 56 \\
\hline
\end{tabular}

${ }_{1}^{1} \mathrm{pH}$ in $\mathrm{H}_{2} \mathrm{O}$ 1:2.5; $\mathrm{P}$ and $\mathrm{K}$ : extracted by Mehlich; $\mathrm{Ca}, \mathrm{Mg}$ and $\mathrm{Al}$ : extracted by $\mathrm{KCl} ; \mathrm{H}+\mathrm{Al}$ : extracted by calcium acetate; $\mathrm{CEC}$ : cation exchange capacity at $\mathrm{pH} 7.0$; $\mathrm{SB}$ : sum of bases; $\mathrm{S}_{-} \mathrm{SO}_{4}{ }^{2-}$ : extracted by barium chloride; $\mathrm{OM}$ : organic matter; V: percentage saturation by bases.

Throughout the study period, when the rainfall was insufficient the pasture was irrigated and the water depth was maintained and calculated as a function of evapotranspiration of the culture (ETc). The meteorological information observed during the study period used to calculate ETc was provided by an automatic weather station located $550 \mathrm{~m}$ from the experimental area (Figure 1).

The period between 1 October and 24 December, which encompasses the first three cuttings, was used for pasture adaptation. As was done before the liming, the pasture was intensively managed and received high doses of $\mathrm{N}$. This period was used as an adaptation period to reduce the $\mathrm{N}$ in the soil so that the mombaça grass would respond to the treatments and not the $\mathrm{N}$ available in the soil.

To evaluate the last four cuttings, the plants were collected with a $0.5 \times 0.5 \mathrm{~m}$ metal square and cut with steel scissors $0.3 \mathrm{~m}$ from the soil surface. After each experimental cutting, the entire study area was uniformly cut at the same height, and the resulting waste was removed. The material collected in each $0.25 \mathrm{~m}^{2}$ cutting was placed in a plastic bucket, identified and immediately weighed, thus

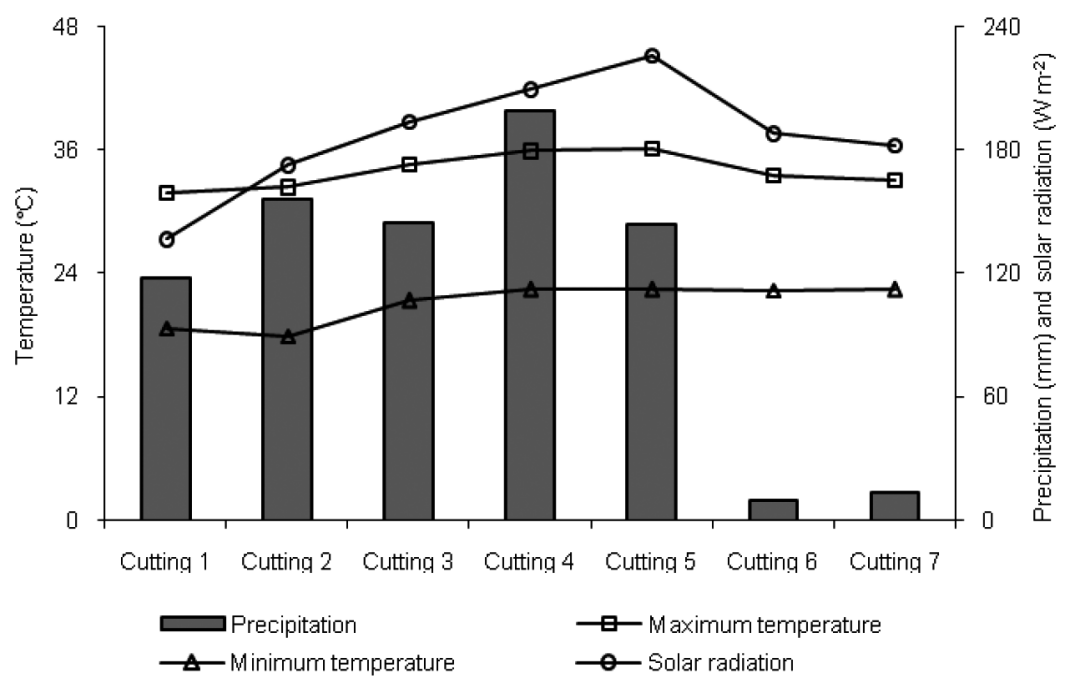

Figure 1. Values of climatic variables observed during the study period. Santa Teresa, ES. October/2011 to April/2012. 
providing the fresh weight of the grass. Subsequently, a representative sample of approximately $0.4 \mathrm{~kg}$ of the forage was taken from the collected material, placed in a paper bag, identified and placed in a forced air oven with a temperature between 60-65 ${ }^{\circ} \mathrm{C}$ until reaching a constant weight to determine the pre-drying mass. After drying, the samples were ground in a Willey grinder with a 1-mm sieve and placed in polyethylene bags. Subsequently, the ground material was placed in the oven again to remove the residual moisture. Dry matter production (DMP) per hectare was determined with the fresh weight of the material collected from the $0.25 \mathrm{~m}^{2}$ plot and the level of dry matter obtained after processing the sample according to the following formula: DMP $=[\% \mathrm{DM} \times(\mathrm{FM} \times 40000)] / 100$, where DMP is dry matter production in $\mathrm{kg} \mathrm{ha}^{-1} ; \% \mathrm{DM}$ is percent dry matter of the sample after processing; FM is fresh matter in $\mathrm{kg}$, collected from the $0.25 \mathrm{~m}^{2}$ plot; and 40000 is a factor used to convert production into hectares.

The above-ground plant matter was chemically analysed to determine the concentrations of nitrogen, phosphorus, potassium, calcium, magnesium and sulphur according to the method described by Malavolta et al. (1997). Data from the chemical analysis of the forage plants and DMP were used to calculate the nutrient extraction in each cutting using the formula: $\mathrm{NE}=0.001 \times(\mathrm{DM} \times \mathrm{CN})$, where $\mathrm{NE}$ is nutrients extracted in $\mathrm{kg} \mathrm{ha}^{-1}$; DM is dry matter in $\mathrm{kg} \mathrm{ha}^{-1}$; $\mathrm{NC}$ is nutrient concentration in $\mathrm{g} \mathrm{kg}^{-1}$; and 0.001 is a factor used to convert nutrient extraction into $\mathrm{kg} \mathrm{ha}^{-1}$. The results represent the sum of the nutrient extractions of the last four cuttings.

The data were subjected to an analysis of variance and regression equations were fitted according to the significance of the variables. A significance level of 5\% was adopted in all of the statistical tests and tests were performed using the program SAS.

\section{Results and Discussion}

The increased supply of $\mathrm{N}$ resulted in greater DMP of mombaça grass (Figure 2). Calcium nitrate produced the highest DMP response for increasing doses of $\mathrm{N}$, followed by ammonium sulphate and urea. At the maximum dose of $\mathrm{N}$, the application of ammonium sulphate and calcium nitrate produced a DMP 14 and 27\% greater than that produced by urea, respectively.

The increase in the DMP of tropical pasture grass plants as a function of increasing doses of $\mathrm{N}$ was presented by Martuscello et al. (2015) and Cunha et al. (2012). According to Fagundes et al. (2006), the supply of this nutrient is indispensable in pasture production systems, when $\mathrm{N}$ resulting from soil organic matter mineralization is not sufficient

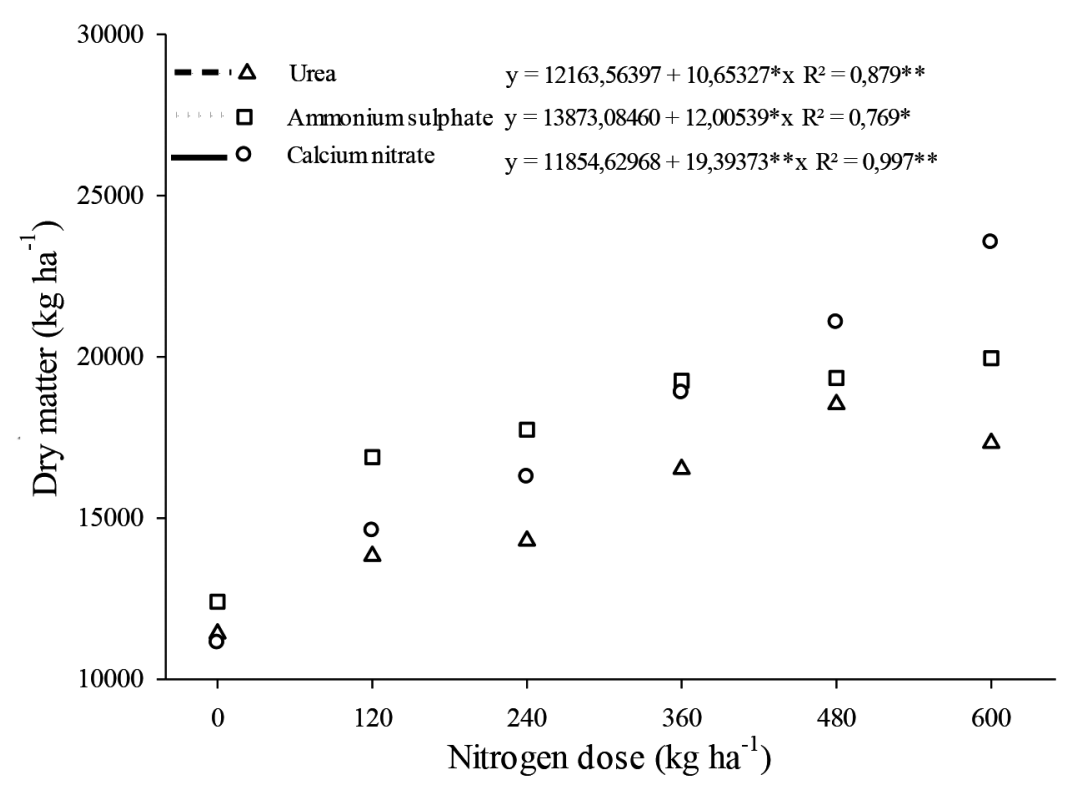

Figure 2. Accumulated production of dry matter from mombaça grass submitted to sources and doses of nitrogen. $*$ and $* *: \mathrm{p}<0.05$ and $\mathrm{p}<0.01$ respectively. 
to assist the Gramineae plant demand with high productive potential.

According to the presented results, the DMP using calcium nitrate as a source of $\mathrm{N}$ was higher than the other sources in the elevated $\mathrm{N}$ doses. This probably is due to the nitrate in the soil dynamics and its chemical characteristics, reducing $\mathrm{N}$ losses significantly with its application.

Compared to the other sources, urea application promoted inferior response to DMP. Similar results were presented by Costa et al. (2010), evaluating Brachiara brizantha production, using urea and ammonium sulphate as $\mathrm{N}$ sources. According to Costa et al. (2003), the transformations which occur with this soil fertilizer, the possibilities of $\mathrm{N}$ losses, mainly through ammonium volatilization may explain the presented results, even with the management adopted during the dose applications.

$\mathrm{N}$ extraction was influenced by the sources and doses of N. An increase in the applied $\mathrm{N}$ dose resulted in a greater extraction of this nutrient by the plants (Figure 3 ). The greatest $\mathrm{N}$ extraction was obtained with the application of calcium nitrate, followed by ammonium sulphate and urea, which corroborates the relationship between DMP and nutrient extraction observed by Costa et al. (2008) for Brachiaria brizantha cv. Xaraés. An increase in N extraction with higher doses of $\mathrm{N}$ was also reported by Costa et al. (2010) for Brachiaria brizantha cv. Marandu. Figure 3 shows that the data best fit a quadratic model; Primavesi et al. (2004) reported similar observations in pastures of Coastcross grass. In the treatments that received the maximum $\mathrm{N}$ dose, $\mathrm{N}$ extraction by mombaça grass was 148 , 160 and $197 \%$ greater than that of the control for urea, ammonium sulphate and calcium nitrate, respectively, which shows that this crop requires high levels of this nutrient to maintain high forage production levels.

Phosphorus (P) extraction by mombaça grass was influenced by the different sources and doses of $\mathrm{N}$ (Figure 4). For the $\mathrm{N}$ sources calcium nitrate and urea, the data fit a linear model in which the increase in the dose of $\mathrm{N}$ promoted greater $\mathrm{P}$ extraction. The increase in $\mathrm{P}$ extraction with higher $\mathrm{N}$ doses is due to the greater DMP of mombaça grass, which requires greater quantities of $\mathrm{P}$ to promote increased production. These results agree with results obtained by Costa et al. (2008) and Costa et al. (2010) who evaluated nutrient extraction in Brachiaria brizantha cv. Marandu and Brachiaria brizantha cv. Xaraés, respectively.

The existing synergism between $\mathrm{N}$ and $\mathrm{P}$ contributed to the increased $\mathrm{P}$ extraction with the higher doses of N. Similar results were obtained by Franco et al. (2007), who documented the synergistic effect of these two nutrients. These authors believe that an increase in $\mathrm{N}$ supply favoured $\mathrm{P}$ absorption in sugar cane. According to Malavolta et al. (1997), the interaction between nutrients, i.e. the capacity that a specific nutrient has to alter the absorption of another because of antagonism, inhibition or

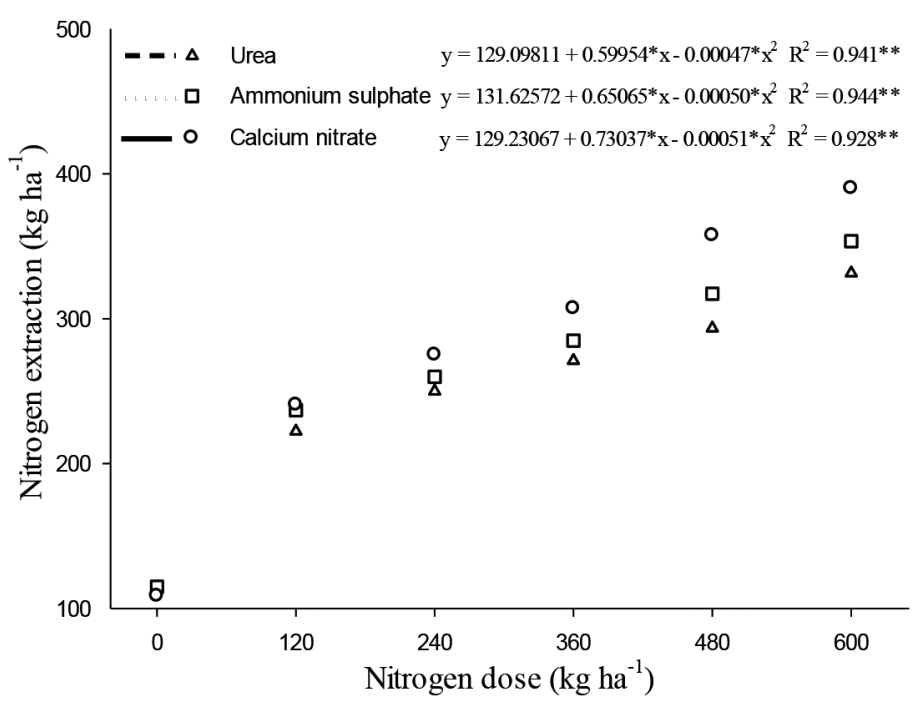

Figure 3. Accumulated nitrogen extraction in mombaça grass plant mass submitted to sources and doses of nitrogen. $*$ and $* *$ : $\mathrm{p}<0.05$ and $\mathrm{p}<0.01$ respectively. 


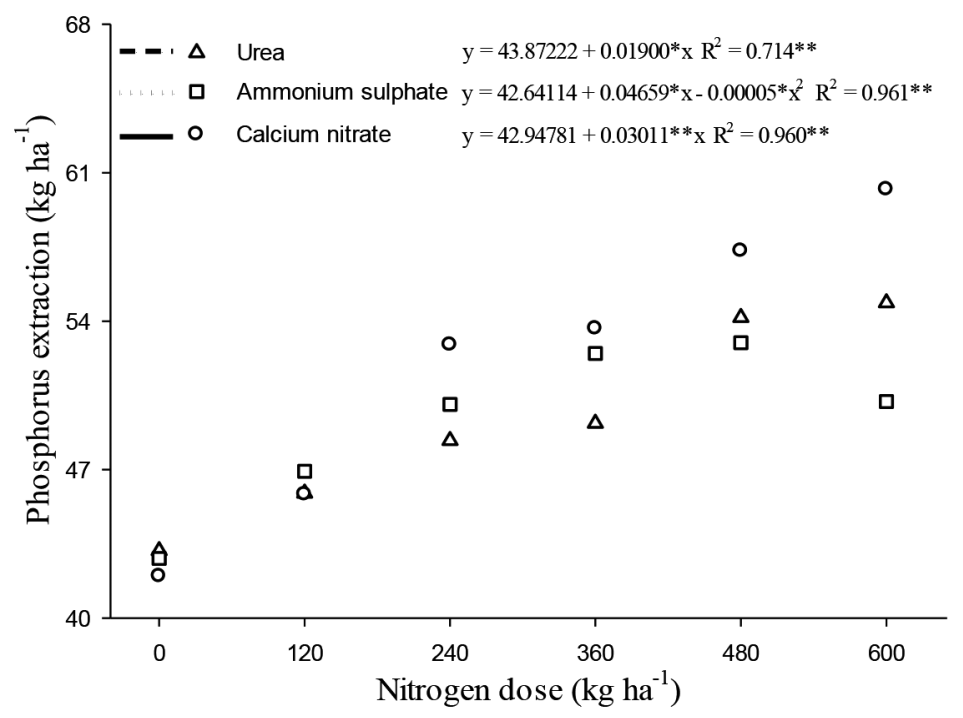

Figure 4. Accumulated phosphorus extraction in mombaça grass plant mass submitted to sources and doses of nitrogen. $*$ and $* *$ : $p<0.05$ and $\mathrm{p}<0.01$ respectively.

existing synergism between the two should also be considered.

The application of $600 \mathrm{~kg} \mathrm{ha}^{-1}$ of $\mathrm{N}$ in the form of urea and calcium nitrate promoted an increase of 26 and $42 \%$ in $\mathrm{P}$ extraction, respectively. The application of high doses of $\mathrm{N}$ (over $465 \mathrm{~kg} \mathrm{ha}^{-1}$ ) in the form of ammonium sulphate reduced $P$ extraction in the plants. These results can be explained by the changes in soil $\mathrm{pH}$ caused by this fertiliser. Sarmento et al. (2008) observed that the application of ammonium sulphate caused a reduction in the levels of $\mathrm{P}$ in pastures of Panicum maximum at the end of the experiment due to the reduced soil $\mathrm{pH}$ and the subsequent formation of insoluble phosphates of Fe and Al. Thus in the present study, the soil acidification, the increased concentration of aluminium and the reduced availability of $\mathrm{P}$ caused by the application of ammonium sulphate contributed to the reduced availability of $\mathrm{P}$ in the soil and the consequent reduced extraction of this nutrient by the plants at higher doses of N. Furthermore, the increased concentration of sulphur in the soil caused by the application of high doses of ammonium sulphate could have contributed to the reduced $\mathrm{P}$ extraction due to the existing antagonism between these nutrients.

The increased $\mathrm{N}$ supply in the different sources caused a linear increase in the extraction of potassium (K) and calcium (Ca), except in the case of calcium nitrate. For both nutrients, calcium nitrate produced greater rates of extraction followed by ammonium sulphate, which shows that these results are intimately connected with the DMP of the forage plant (Figures 5 and 6).

When $600 \mathrm{~kg} \mathrm{ha}^{-1}$ of $\mathrm{N}$ in the form of calcium nitrate were applied to the mombaça grass, $11 \%$ more $\mathrm{K}$ was extracted than when urea was applied. For ammonium sulphate, the K extraction was 5\% higher than when urea was used. Experiments showing differences in $\mathrm{K}$ extraction due to differences in $\mathrm{N}$ source by tropical forage plants were presented by Costa et al. (2009). These authors observed a higher $\mathrm{K}$ extraction in Brachiaria brizantha cv. Marandu with ammonium sulphate than with urea. These results were attributed to the higher DMP of the forage plants with the use of ammonium sulphate.

The existing synergistic effect between $\mathrm{N}$ and $\mathrm{K}$ and between $\mathrm{N}$ and $\mathrm{Ca}$ could have contributed to the increased extraction of the cations $\mathrm{K}$ and $\mathrm{Ca}$ by mombaça grass. Cantarela (2007) reported the synergism existing between $\mathrm{N}$ and $\mathrm{K}$ and between $\mathrm{N}$ and Ca. Faroni et al. (2009) observed that increased nitrogen fertilisation resulted in increased $\mathrm{K}$ absorption in sugar cane plants, and the author attributed this behaviour to the synergism between the nutrients. When calcium nitrate was used, $\mathrm{Ca}$ extraction by the plants occurred in a quadratic manner, with greater extraction values reported with calcium nitrate than with other sources of $\mathrm{N}$. These results can be explained by the indirect supply of 


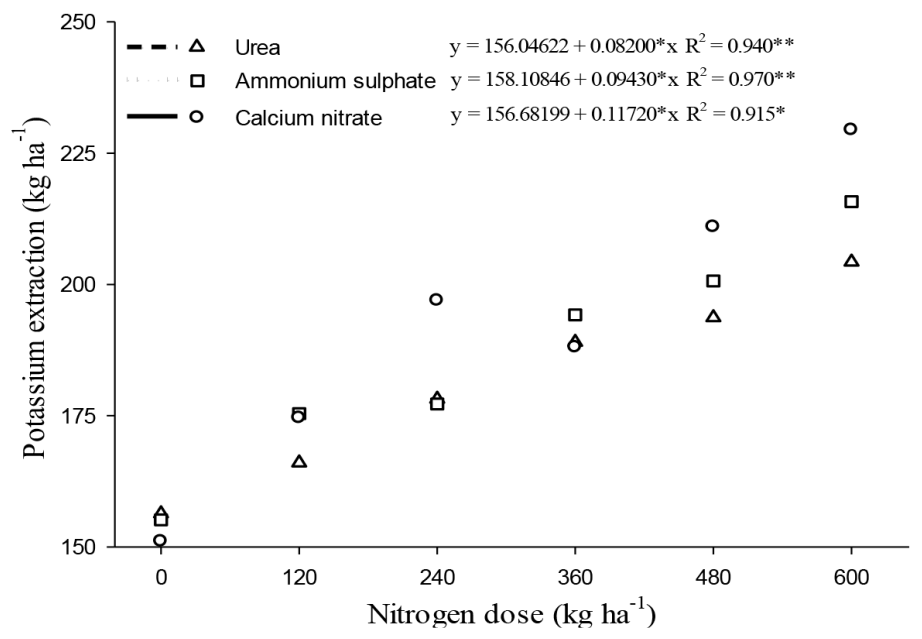

Figure 5. Accumulated potassium extraction in mombaça grass plant mass submitted to sources and doses of nitrogen. $*$ and $* *: \mathrm{p}<0.05$ and $\mathrm{p}<0.01$ respectively.

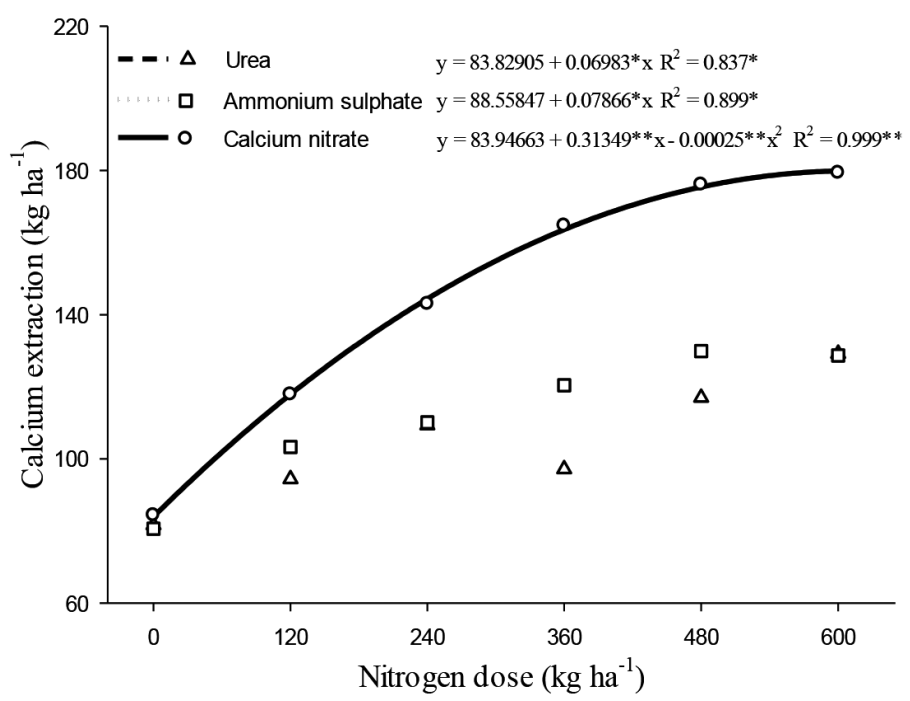

Figure 6. Accumulated calcium extraction in mombaça grass plant mass submitted to sources and doses of nitrogen. * and $* *: \mathrm{p}<0.05$ and $\mathrm{p}<0.01$ respectively.

Ca to the soil through the nitrogen fertiliser, which allows a greater absorption of this nutrient by plants.

The application of $\mathrm{N}$ in the form of urea and ammonium sulphate caused a linear increase in magnesium $(\mathrm{Mg}$ ) extraction (Figure 7). The application of $600 \mathrm{~kg} \mathrm{ha}^{-1}$ of $\mathrm{N}$ in the form of urea and ammonium sulphate promoted an increase of 44 and $72 \%$ in $\mathrm{Mg}$ extraction, respectively.

High doses of $\mathrm{N}$ (over $363 \mathrm{~kg} \mathrm{ha}^{-1}$ ) in the form of calcium nitrate reduced $\mathrm{Mg}$ extraction in the plants. This reduction can be explained by the increased $\mathrm{Ca}$ concentration in the soil and the consequent reduction in $\mathrm{Mg}$ absorption. Calcium nitrate contains $19 \% \mathrm{Ca}$; therefore $735 \mathrm{~kg} \mathrm{ha}^{-1}$ of $\mathrm{Ca}$ were indirectly supplied to the soil in the treatment where the maximum $\mathrm{N}$ dose was applied. According to Malavolta (2006), $\mathrm{Ca}$ and $\mathrm{Mg}$ ions compete for the same absorption sites in plants. Therefore, the excess of one element results in the decreased absorption of the other because of competitive inhibition. Medeiros et al. (2008) and Salvador et al. (2011) showed that decreased $\mathrm{Mg}$ absorption occurred in corn and soy, respectively, in the presence of increased soil concentrations of $\mathrm{Ca}$. 


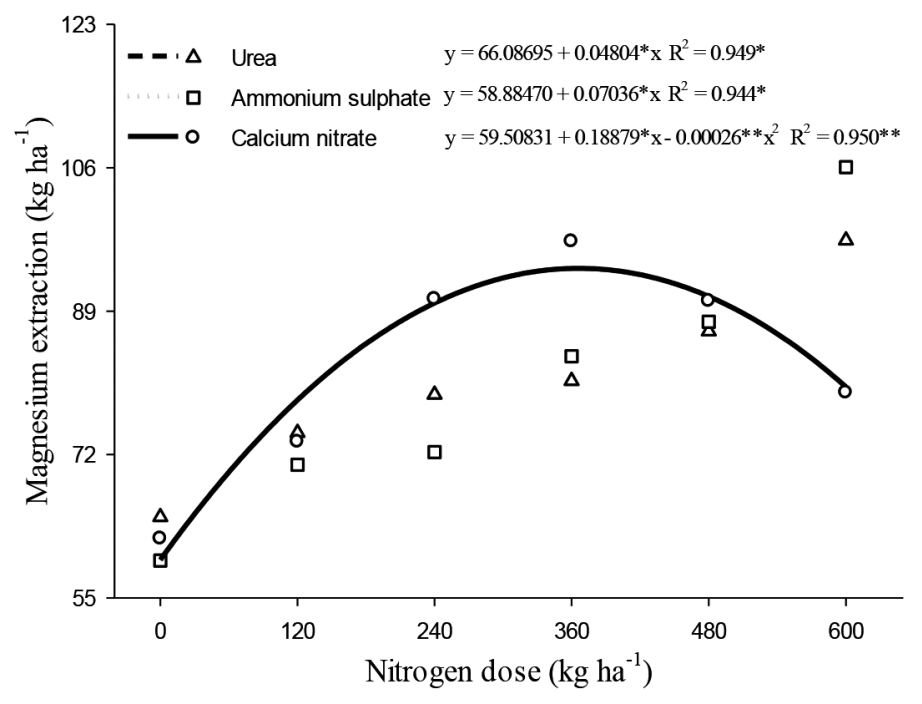

Figure 7. Accumulated magnesium extraction in mombaça grass plant mass submitted to sources and doses of nitrogen. * and $* *$ : $p<0.05$ and $\mathrm{p}<0.01$ respectively.

Doses and sources of $\mathrm{N}$ had a significant impact on sulphur (S) extraction by mombaça grass. For all $\mathrm{N}$ sources, $\mathrm{S}$ extraction increased linearly with increasing $\mathrm{N}$ doses (Figure 8). A similar result was found by Batista \& Monteiro (2006) in a study of Brachiaria brizantha $\mathrm{cv}$. Marandu. These authors observed marked increases in $\mathrm{S}$ extraction with increasing $\mathrm{N}$ doses in plants.
For the greatest dose of $\mathrm{N}, \mathrm{S}$ extraction was $103 \%$ greater with ammonium sulphate than with urea. Similar results were observed by Costa et al. (2009). These authors found that $105 \%$ more $\mathrm{S}$ was extracted when the highest dose of $\mathrm{N}\left(300 \mathrm{~kg} \mathrm{ha}^{-1}\right)$ was applied in the form of ammonium sulphate than urea. According to Primavesi et al. (2004), this sharp increase in $\mathrm{S}$ extraction with ammonium

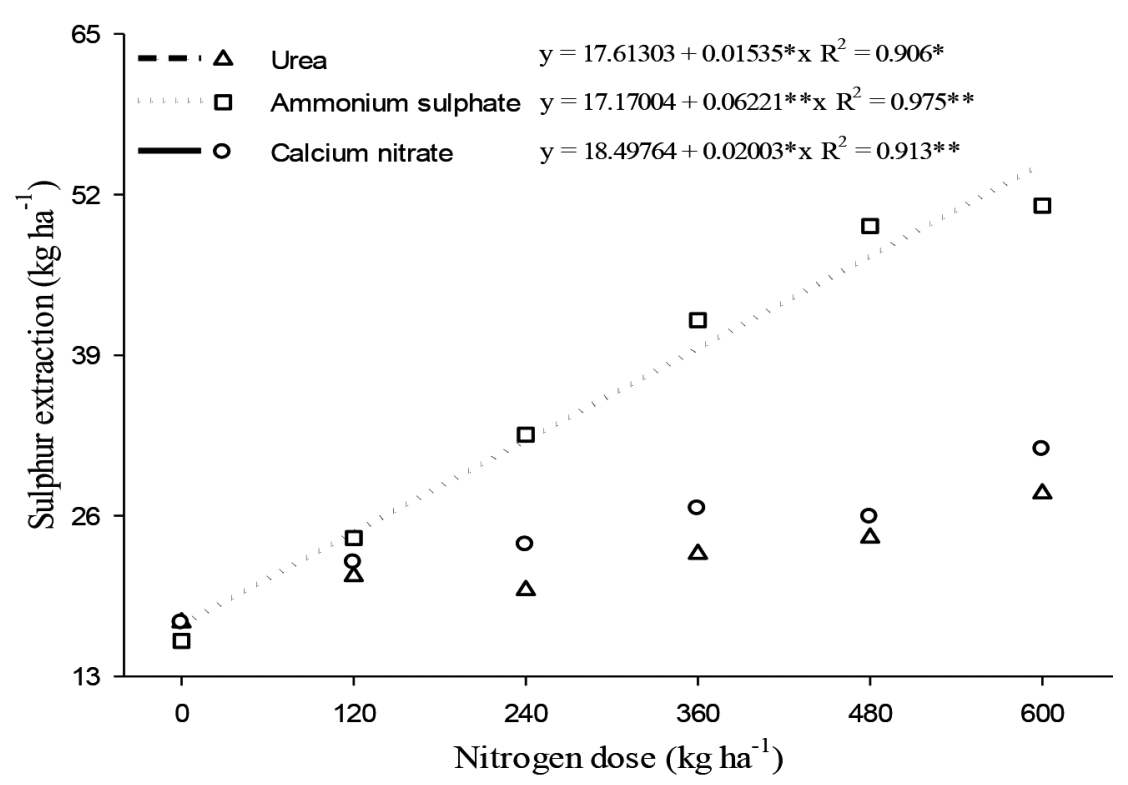

Figure 8. Accumulated sulphur extraction in mombaça grass plant mass submitted to sources and doses of nitrogen. $*$ and $* *: \mathrm{p}<0.05$ and $\mathrm{p}<0.01$ respectively. 
sulphate is due to the fact that $24 \%$ of this fertiliser is $\mathrm{S}$, which is indirectly supplied to the soil and made available to the plants.

\section{Conclusions}

The increase in nitrogen supply results in greater nutrient extraction by mombaça grass due to a higher dry matter production.
The nutrients which are associated with nitrogen in the nitrogen fertilizers may, through synergism or antagonism, potentiate or reduce other nutrient extraction by mombaça grass.

The nitrogen fertilization on pastures may be followed by other nutrient management considering the characteristics of each nitrogen source that is used, aiming to avoid the nutritional imbalance or the depauperation of soil fertility.

\section{Literature Cited}

Almeida, M.C.C.; Chiari, L.; Jank, L.; Valle, C.B.

2011. Diversidade genética molecular entre cultivares e híbridos de Brachiaria spp. e Panicum maximum. Ciência Rural, 41: 1998-2003.

Alves, R.C.; Bremm, C.; Nunes, C.L.R.; Barro, R.S.; Barth Neto, A.; Schons, R.M.T.; Caetano, L.A.M.; Carvalho, P.C.F. 2015. Suprimento de nitrogênio para culturas de verão pela aplicação antecipada em azevém pastejado por ovino. Revista Brasileira de Ciência do Solo, 39: 1406-1415.

Barcellos, A.O.; Ramos, A.K.B.; Vilela, L.; Martha Junior, G.B.

2008. Sustentabilidade da produção animal baseada em pastagens consorciadas e no emprego de leguminosas exclusivas, na forma de banco de proteína, nos trópicos brasileiros. Revista Brasileira de Zootecnia, 37: 51-67.

Batista, K.; Monteiro, F.A.

2006. Respostas morfológicas e produtivas do capim-marandu adubado com doses combinadas de nitrogênio e enxofre. Revista Brasileira de Zootecnia, 35: 1281-1288.

Cantarela, $\mathrm{H}$.

2007. Nitrogênio. In: Novais, R.F.; Alvarez V., V.H.; Barros, N.F.; Fontes, R.L.F.; Cantarutti, R.B.; Neves, J.C.L. (eds.). Fertilidade do solo. Sociedade Brasileira de Ciência do Solo, Viçosa, Brasil, pp. 375-470.

Costa, K.A.P.; Araujo, J.L.; Faquin, V.; Oliveira, I.P.; Figueiredo, F.C.; Gomes, K.W.

2008. Extração de macronutrientes pela fitomassa do capimxaraés em função de doses de nitrogênio e potássio. Ciência Rural, 38: 1162-1166.

Costa, K.A.P.; Faquin, V.; Oliveira, I.P.; Severiano, E.C.; Simon,

G.A.; Carrijo, M.S.

2009. Extração de nutrientes do capim-marandu sob doses e fontes de nitrogênio. Revista Brasileira de Saúde e Produção Animal, 10: 801-812.

Costa, K.A.P.; Oliveira, I.P.; Severiano, E.C.; Sampaio, F.M.T.;

Carrijo, M.S.; Rodrigues, C.R.

2010. Extração de nutrientes pela fitomassa de cultivares de Brachiaria brizantha sob doses de nitrogênio. Ciência Animal Brasileira, 11: 307-314.

Costa, M.C.G.; Vitti, G.C.; Cantarella, H.

2003. Volatilização de $\mathrm{N}-\mathrm{NH}_{3}$ de fontes nitrogenadas em cana-de-açúcar colhida sem despalha a fogo. Revista Brasileira de Ciência do Solo, 27: 631-637.
Cunha, F.F.; Ramos, M.M.; Alencar, C.A.B.; Oliveira, R.R.; Cóser, A.C.; Martins, C.E.; Cecon, P.R.; Araújo, R.A.S.

2012. Produtividade da Brachiaria brizantha cv. Xaraés em diferentes manejos e doses de adubação, períodos de descanso e épocas do ano. Idesia, 30: 75-82.

Fagundes, J.L.; Fonseca, D.M.; Morais, R.V.; Mistura, C.; Vitor, C.M.T.; Gomide, J.A.; Nascimento Junior, D.; Santos, M.E.R.; Lambertucci, D.M.

2006. Avaliação das características estruturais do capimbraquiária em pastagens adubadas com nitrogênio nas quatro estações do ano. Revista Brasileira de Zootecnia, 35: 30-37.

Faroni, C.E.; Trivelin, P.C.O.; Franco, H.C.J.; Vitti, A.C.; Otto, R.; Cantarella, $\mathrm{H}$.

2009. Estado nutricional da cultura de cana-de-açúcar (canaplanta) em experimentos com ${ }^{15} \mathrm{~N}$. Revista Brasileira de Ciência do Solo, 33: 1919-1927.

Franco, H.C.J.; Bologna, I.R.; Faroni, C.E.; Vitti, A.C.; Trivelin, P.C.O.

2007. Acúmulo de macronutrientes em cana-de-açúcar em função da adubação nitrogenada e dos resíduos culturais incorporados ao solo no plantio. Bragantia, 66: 669-674.

Malavolta, E.; Vitti, G.C.; Oliveira, S.A.

1997. Avaliação do estado nutricional das plantas: princípios e aplicações. 2.ed. Potafos, Piracicaba, Brasil, 319 pp.

Malavolta, E.

2006. Manual de nutrição de plantas. Ceres, São Paulo, Brasil, $631 \mathrm{pp}$.

Martuscello, J.A.; Silva, L.P.; Cunha, D.N.F.V.; Batista, A.C.S.;

Braz, T.G.S.; Ferreira, P.S.

2015. Adubação nitrogenada em capim-massai: morfogênese e produção. Ciência Animal Brasileira, 16: 1-13.

Medeiros, J.C.; Albuquerque, J.A.; Mafra, A.L.; Rosa, J.D.; Gatiboni, L.C.

2008. Relação cálcio:magnésio do corretivo da acidez do solo na nutrição e no desenvolvimento inicial de plantas de milho em um Cambissolo Húmico Álico. Semina, 29: 799-806.

Prezotti, L.C.; Gomes, J.A.; Dadalto, G.G.; Oliveira, J.A. 2007. Manual de recomendação de calagem e adubação para o Estado do Espírito Santo. $5^{\text {a }}$ aproximação. SEEA/ INCAPER/CEDAGRO, Vitória, Brasil, 305 pp. 
Primavesi, A.C.; Primavesi, O.; Corrêa, L.A.; Cantarella, H.; Silva, A.G.; Freitas, A.R.; Vivaldi, L.J.

2004. Adubação nitrogenada em capim-coastcross: efeitos na extração de nutrientes e recuperação aparente do nitrogênio. Revista Brasileira de Zootecnia, 33: 68-78.

Primavesi, A.C.; Primavesi, O.; Corrêa, L.A.; Cantarella, H.; Silva, A.G. 2005. Absorção de cátions e ânions pelo capim-coastcross adubado com ureia e nitrato de amônio. Pesquisa Agropecuária Brasileira, 40: 247-253.

Salvador, J.T.; Carvalho, T.C.; Lucchesi, L.A.C.

2011. Relações cálcio e magnésio presentes no solo e teores foliares de macronutrientes. Revista Acadêmica: Ciências Agrárias e Ambientais, 9: 27-32.

Santos, H.G.; Jacomine, P.K.T.; Anjos, L.H.C.; Oliveira, V.A.; Lumbreras, J.F.; Coelho, M.R.; almeida, J.A.; Cunha, T.J.F.; Oliveira, J.B. 2013. Sistema brasileiro de classificação de solos. 3.ed. Embrapa, Brasília, Brasil, 353 pp.
Santos, M.P.; Castro, Y.O.; Marques, R.C.; Pereira, D.R.M.; Godoy, M.M.; Reges, N.P.R.

2016. Importância da calagem, adubações tradicionais e alternativas na produção de plantas forrageiras: Revisão. PUBVET, 10: 1-12.

Sarmento, P.; Rodrigues, L.R.A.; Cruz, M.C.P.; Lugão, S.M.B.; Campos, F.P.; Centurion, J.F.; Ferreira, M.E.

2008. Atributos químicos e físicos de um Argissolo cultivado com Panicum maximum Jacq. cv. IPR-86 Milênio, sob lotação rotacionada e adubado com nitrogênio. Revista Brasileira de Ciência do Solo, 32: 183-193.

Taiz, L.; Zeiger, E.

2009. Fisiologia vegetal. 4.ed. Artmed, Porto Alegre, Brasil, 819 pp. 